\title{
Linguistic Movements in Hong Kong: Linguistic Nationalism and Cultural Hegemony
}

\author{
Fung-Ming Hui, M.A. BSocScEd. \\ National Tsing Hua University, Taiwan
}

$\begin{array}{cl}\text { Doi: 10.19044/elp.v8no1a13 } & \text { URL:http://dx.doi.org/10.19044/elp.v8no1a13 } \\ & \\ \text { Submitted: 25 January 2021 } & \text { Copyright 2021 Author(s) } \\ \text { Accepted: 16 March 2021 } & \text { Under Creative Commons BY-NC-ND } \\ \text { Published: 31 March 2021 } & \text { 4.0 OPEN ACCESS }\end{array}$

\begin{abstract}
This paper focuses on exploring the Hong Kong's Linguistic Nationalism and localist linguistics movements, including First 'Chinese' Movement from 1967 to 1970, Second 'Chinese' Movement in 1978 in Hong Kong British- Colonial Governance and Anti-Putonghua, and Pro-Cantonese Movement from 2008 in HKSAR governance.
\end{abstract}

Keywords: Hong Kong, Linguistic Nationalism, First 'Chinese' Movement, Second 'Chinese' Movement, Pro-Cantonese Movement

\section{Introduction}

This paper aims to explore the Hong Kong's Linguistic Nationalism and localist linguistics movements, including First 'Chinese' Movement (1967 to 1970), Second 'Chinese' Movement (1978) in Hong Kong British-Colonial Governance and Anti-Putonghua, and Pro-Cantonese Movement from 2008 in HKSAR governance. This was achieved by using a framework that incorporated the theoretical discussion on Gramsci's cultural hegemony and Anderson's paradigm on linguistic nationalism. This paper shows the importance of Cantonese as a culture combination of Hong Kong ethnicity's ancient history and myth because of its linguistic territory and the cultural hegemony through tremendous influence on official nationalism's impacts that is shaping the identity determination of most Hongkonger.

\section{Theoretical Framework: Linguistic Nationalism and Cultural Hegemony}

Anderson's ideas on the linguistics of 'simultaneity inhomogeneous empty time' (Anderson, 1991) creates the simultaneity of the imagination of the ethnic groups. It is 'a simultaneity of past and future in an instantaneous present. An idea of homogenous, empty time in which simultaneity is, as it 
were, transverse, cross time, marked not by prefiguring and fulfillment, buy by temporal coincidence, and measured by clock and calendar.' (Anderson, 1991). Ethnic group members may not know each other, but through same linguistic, they will feel they are connected and related to one another in simultaneity inhomogeneous empty time. An example is their same reaction and collective memories in reading the context novels by same linguistic. Therefore, this means that the ethnic groups will develop "We" concepts of us and "Our" linguistics in the meanwhile, but distinguish the "They" concepts of them and "Their" linguistics from reading and speaking.

In Benedict Anderson's explanation, Novels and Newspapers were the media of imagination to create 'simultaneity' of ethnic group (Anderson, 1991). For Novels, Anderson stated that the imagination of the ethnicity would be bounded by the context of their experiences. No matter the novels that have been described, it will create a social space to let the ethnic group feel the similar backgrounds. This is because it was written the way an ethnic group is familiar with, which is the same language that they are both using day to day. The 'socioscape' in the novels and the protagonist, as Anderson describes, are pointing to the image as 'our' society and 'our generation young man' by the readers of the same languages. Similar to novels, newspapers are also functioning as a medium of the imagination of ethnicity. When the newspaper readers are reading, Anderson describes it as a 'historically clocked' imagination community creation. The 'simultaneity' will happen in every reader's mind as the newspaper will create the territory of provinciality that mentions the daily happenings of that which is in certain 'spaces,' of which most are related to 'our' society. The imagination of the ethnicity community is rooted in the imagination of the daily society. Another one is 'plurality,' referring to where and what the newspaper's reporters choose to report. This matters since the pictures they want to project are similar to the locals' ethnicity's daily. That is why there are 'reading coalition' formed by the languages to share a similar experience. The printed languages have helped certain thousands of readers to understand each other's thought. Anderson describes it as 'national printed languages' since it showed a national writing system and own languages' publications. Of course, due to technological development, he added that radio and television was another kind of medium to express the 'simultaneity' of the ethnicity. The linguistic nationalism will further have created populist nationalism movements and is the beginning of the creation of an imagined community.

In his books, Anderson (1991) also mentioned the official nationalism through government policy. For instance, in language policy, the appointment of government official and education to youth is related to the linguistic imagination of the ethnicity and will thus create a stronger nationalist movement. The official nationalism launched through government policy is the reaction to and is the counter back to the rise of ethnicity linguistic nationalism. It can be divided into two main streams: successful or not 
triumphant official nationalism. The triumphant official nationalism can assimilate the ethnicity to become part of their mother-colonial countries nationality members. For not triumphant official nationalism, in the government appointment, ethnicity will always be exempted at the top tier of the colonial motherland-government official position. Therefore, in his words, 'the end of the educational/administrative route' of the local ethnicity is the territory that they lived. The youth can only be imagined getting into the best colonial-university on their colonial land. Their route in administration is also only on their colonial-land. More importantly, the language policy of the government will eliminate the other languages in the basic education system. It is the 'anticipatory strategy' of the government to prevent their 'domination group in the country' being marginalized because of the rise of linguistic nationalism. However, in the meanwhile, due to the needs of setting up for the local colonial governance, the bilingual talents would be trained through the dominate-education system. These bilingual youths under colonial governance are majorly a part of the imagined community as they will break down the racism critiques. Through bilingual, they can use mother-colonial languages to transform the media's readers, which can be colonizers, to become a part of ethnicity members. Therefore, in summary, the official nationalism in government appointment and education policy will onlylet the youth and the ethnicity to imagine that their colonial land is the destination of their places in life. Hence, the territory was created. The dominant colonial language policy will also create the chance of counter back from the local ethnicity as the bilingual talents will be trained. Also, they can spread the colonial's oppression in bilingual, resulting to the rise of the nationalist movement and nationalism.

Furthermore, official nationalism contained the cultural hegemony by the government. In Gramsci's explanation, hegemony is seen as a 'dominance or power ever' or 'the leadership of a class over allies' in Marxist perspective. He thought of cultural hegemony as a non-coercive means of maintaining bourgeois dominance in capitalist societies. 'Superior culture' would be created in such circumstances. However, the alliances and coalitions are also made and remade in those creating process. These processes presuppose not merely the articulation but, crucially, the aggregation of interests. Gramsci mentioned that languages are critical because it cannot be separated from all aspects of social life. That is why the cultural hegemony will try to control the languages of schools, newspapers, popular and artist-writers, cinema, radio and religious group (Francese, 2013). Therefore, cultural hegemony is tremendously influenced by the linguistic hegemony, i.e., the official nationalism.

In sociology literature, the term "nationalism" has two main perspectives, including liberal nationalism and ethnic nationalism. These perspectives is influenced deeply by anthropologist Benedict Anderson's work entitled 'Imagined Communities.' As Smith (2010, p.10-16) stated, 
ethnic nationalism refers to 'territory and ethnicity' as a 'religion' of public culture to draw boundaries between each other. The culture such as languages, religion, customs, institutions, laws, folklore, architecture, dress, food, music, arts even color, and physique are all parts of the ancient history and myths of each ethnicity since the people share collective memories and tied members together to separate them from outsiders (Smith, 2010). As Smith (2010) argued, culture can be able to build a collective identity and sense of belongings on the ethnicity's 'homeland,' and people are willing to undergo self-sacrifice to protect it. The liberal nationalism provides an internationalist perspective to explain the making of nationalism (Smith, 2010). The identity construction based on the belonging of political life in nations respect the liberal values such as freedom, peace, social justice, the rule of law, and equity of human rights. Thus, their concern will focus on the political values of citizens. That is why the liberal nationalist believed in the possibility of building a melting pot of political, cultural, and ethnic identity such as the USA, Canada, and France. However, the liberal nationalism have failed to explain the culture's uniqueness of each ethnic groups. In the meanwhile, the ethnic nationalism also ignores the Xenophobia and exclusionary critiques. Therefore, from this paper's perspectives, Benedict Anderson's approach to linguistic nationalism has become the 'Third Route' between liberal nationalism and ethnic nationalism. Table 1 illustrates the difference between liberal, ethnic, and linguistic nationalism.

As Anderson (1991) insisted, the collective name, common myth, shared history, shared culture, territory, and sense of solidarity has a strong sense of belongings and are transited into the same linguistics. This is because the words in writing and speaking in ethnicity included all the myths, histories, and all of the above cultures to experience the inheritance of the ethnicity by each families. Linguistic nationalism not only inherited Ethnic nationalism but was also impacted by the political values of Liberal Nationalism. This also include the political identity and the universal values of freedom, peace, social justice, the rule of law and equity of human rights. The will to sacrifice time in learning linguistic is already a proof to sacrifice for the ethnicity. Anderson's 'Third Road' of linguistic nationalism argues that linguistic would not be xenophobia and exclusionary since it is inclusive when the outsiders are willing to learn linguistics; as a result, they will enter the same imagined communities of the ethnicity (Anderson, 1991). Secondly, linguistic can still be bounded as 'them' versus 'us' to highlight the culture's uniqueness as it will bring the outsiders into a different world of culture (Anderson, 2016).

Therefore, this paper focuses on showing that the Benedict Anderson's works' contribution on the relationship between Linguistic and Nationalism have seldom been discussed. Additionally, this approach is not yet being applied in the recent works, especially in Hong Kong's nationalism discussion. This study can contribute to "The Third Road" of 
nationalism discussion other than Liberal nationalism and Ethnic nationalism in Hong Kong. This paper also attempt to show that the Linguistic Nationalism in Hong Kong have already started from the British colonial rule, and the Linguistics nationalist movements in Hong Kong have always been resisting the official nationalism (Britishlization before 1997; Mainlandlization after 1997). Politically speaking, Linguistic nationalist movements in Hong Kong is the counter back against the cultural hegemony from the government's official nationalism. Socially speaking, Linguistic nationalist movements in Hong Kong is protecting the linguistic autonomy of ethnicity. Culturally speaking, Linguistic nationalist movements in Hong Kong is defending mother-tongue linguistics.

\section{Case Analysis}

The following three cases were picked as examples of linguistic nationalist and localist movement in Hong Kong as they both shared the similarities of the nationalist movement in defending mother-tongue linguistics, the linguistic autonomy of ethnicity, and the counter back of cultural hegemony through government's official nationalism.

\section{Anti-Putonghua and Pro-Cantonese Movement in HKSAR Governance}

Anti-Putonghua and Pro-Cantonese Movements in HKSAR governance have been the symbol of Hong Kong Nationalism and one of the localist movements. These movements are to explore in-depth theoretical nationalism discussion in Hong Kong. As So (2015) thought that the rise of Hong Kong Nationalism is due to the influx of Chinese mainland immigrants and tourists, social inequality and the anti-mainland protests, the similarities of these factors is yet to be identified. Linguistics posed as a symbol of cultural differentiation between the Chinese mainland and Hong Kong. The usage of the Traditional Chinese or speaking Cantonese has meanwhile become the way to define "Are you one of them or us?" Therefore, the significance of linguistic movements in Hong Kong has always been a lens of Hong Kong Nationalism.

Two years after the 1997 handover, the Overview Report on the Hong Kong School Curriculum from the HKSAR Curriculum Development Council already proposed that it is necessary to 'add the learning elements of Putonghua to the overall Chinese language curriculum and put "Teach Chinese in Putonghua" as the remote target.' HKSAR Standing Committee on Language Education and Research was sponsored using 2 billion dollars to launch the Teaching Chinese Languages in Putonghua Program which started from 2008 to 2014. 'The support scheme will be carried out in four phases, providing support to 30 primary schools and 10 secondary schools in each phase. A total of 160 schools will benefit. Each participating school will receive support for three years, including on-site visits by mainland professionals and local consultants in the first year to assist the formulation of 
a school-based programme of using Putonghua to teach Chinese. Local consultants will continue to provide sustained support in subsequent years' (Education Bureau, 2008). Although the final report of the program commissioned by the EdUHK indicated that there is no clear evidence of a positive or negative impact on the effectiveness of Teaching Chinese Languages in Putonghua, the Education Bureau still published an article entitled "Language Learning Support" on its website on January 24, 2014. One of the paragraphs said that "Although the "Basic Law" requires bilingual Chinese and English as the official language, it is close to $97 \%$ of the local population, including some newcomers to Hong Kong. Cantonese (a dialect of Chinese language that is not an official legal language) is used as a common language for home and daily communication. As for the official language of the People's Republic of China, the use of Putonghua is widely used, reflecting the close economic relationship between the Mainland and Hong Kong and the close ties between cultures." Thus, this created controversies among Hong Kong locals as the government seemed to lower the status of Cantonese Chinese. In 2015, the HKSAR Curriculum Development Council's Consultation Paper titled 'Renewal of Chinese Language Education Program (P.1-S.6)' stated that the government would continue to implement Putonghua Teaching Chinese in a school-based format. In addition, they will provide students with more Practical Learning Opportunities of Putonghua. Also, the document also advocates that 'students should have the ability to read simplified characters after mastering traditional characters.'

These education and languages policies created great sentiment from the Hong Kong locals, especially the youth, and many new popular ProCantonese or Anti-Putonghua organizations were being set up during the controversies period (Table 2). They allied with the existing teachers and student organizations, like Progressive Teachers' Alliance, HKFS, Scholarism, Student Unions from CUHK, EdUHK, and HKU, and later organized Protect Cantonese Campaign through street and internet propaganda. For example, in February 2016, Scholarism, Societas Linguistica Hongkongensis, and Scholars said no to PMI and petitioned an open letter to Education Bureau that 'Displaces mother tongue in education cannot be tolerated...After a few generations, the culture will not exist. The reason the Government planned to implement simplified Chinese characters is no doubt paving the way for a cultural change and is also breaking the distinction between China and Hong Kong. When this move is accompanied by increasingly rampant Teaching Chinese in Putonghua, Hong Kong education became in line with China's education.' The movements are still on-going, although the government has removed that controversies article in 2014 and clarified that the government 'does not plan to regulate the learning of simplified Chinese characters at the primary and secondary levels. It does not review textbooks that use simplified Chinese characters, but it does not mean to replace traditional Chinese characters with simplified characters, or to “integrate" or dispel traditional characters.' In 2016, Teaching Chinese in 
Putonghua is still the remote target of the government. As a result, government continiously provide funding support to encourage local school use Putonghua in teaching Chinese.

Why does the conflict between Cantonese and Mandarin matter? In the Hong Kong context, 'Chinese' can be divided into Cantonese Chinese and Mandarin Chinese. Pang (2005) and Qian (2010)'s research already told us that Chinese Cantonese and Mandarin Chinese speaking is different. Hsu pointed out that even in writing, Hong Kong Chinese is still different from the Modern Chinese from Mandarin (Hsu, 2009; Shek, 2006). Thus, different Hong Kong linguistics scholars like Cheung (2002), Cheng(1998), Tse (1997), and Leung (1997) also pointed out that there are tone differences between the speaking of Guangdong Cantonese and Hong Kong Cantonese. The modern Hong Kong Cantonese speaking is created in a context of the colonial governance's long-term English-Cantonese mixed usage and ancient history of folk customs. However, that is why some of the Hong Kong Cantonese vocabularies are unique to the other Cantonese in China and have historical meaning of the Hong Kong ethnicity shared memories (Cheng, 1998; Cheung, 2002; Tse, 1997; Leung, 1997). Therefore, we could further put this context into Anderson and Gramsci's explanation of cultural hegemony and linguistic nationalism. In Anderson's words, as Cantonese usage in Hong Kong has been a long history, many of the languages nouns and adjectives already havebeen contained with myth and ancient history of the ethnicity, like a crooking sexual pervert, Mantis Shrimp, and Moron. The printed capitalism in newspapers, novels, books, radio, and television through Cantonese's long history have drawn boundaries from creating 'us' and 'them' imagined communities.

Moreover, First and Second 'Chinese' movements in Hong Kong British Colonial Governance have fought the recognition of the 'Chinese' in official communication and mother-tongue Cantonese Chinese in the education system. Chinese in regards to official communication was successfully established in 1974, while mother-tongue Cantonese Chinese in the education system was successfully established in the 1990s. Due to the successful two 'Chinese' movement in the British colonial period, Cantonese Chinese has always been the medium of instruction in the education system. Also, it is regarded as the official status of Chinese in the formal communication. Therefore, the boundaries of linguistics, the foundation of Hong Kong Nationalism, have started and has always been reinforced by these two movements.

\section{First 'Chinese' Movement in Hong Kong British-Colonial Governance}

These two movements were anti-colonial governance campaigns from the Hong Kong locals. It mainly proposed that 'Chinese' should be national and official languages in Hong Kong. The Cantonese Chinese, which is the mother tongue of Hong Kong people, should be taught through the education 
system by using traditional characters and in Hong Kong's context usage of vocabularies.

In Law's articles, he stated that, in the 1960s, the British-colonial government formed alliances with local elite Chinese and were appointed as executives and parliament. However, this still limited the elected seats in parliament to ensure the dominance of executive-legislative power and the political closure to local Hong Kong people. Therefore, the channels that reflect opinions to the government is also only limited to few English-speakers leaders in Hong Kong, which refers to only the foreigners or bilingual elites Chinese. These political structures influenced the Hong Kong society. These structures could be seen as the cultural hegemony to promote the official nationalism from Britain as English was the only medium of languages in official communication papers and high education system.

Law further stated that since Hong Kong 1997 future problem has not yet settled, the colonial government also created severe corruption and the economic inequality in society. Furthermore, the 1967 riot is the trigger point to make the anti-colonial sentiment to explode in public. After it, the anticolonial sentiment continued and walked the traditional route. The university student's organizations, notably the HKU \& CUHK Student Press and newspaper's critiques, played the leading role to write disclosures in pushing the government to give in. For example, Lau Nai-Keung, prominent pro-PRC supporter now, has written an article as a university student at that time, 'An autonomous government is undoubtedly the ideal goals (of us), if the authorities can legislate to recognize Chinese as the official language, it will be all-performing and harmless.' The student's alliances 'Fight for Chinese to Become an Official Language Association' also formed a committee with Workers Unions called 'Student-Workers Alliance' to discuss the possibility of launching student's strikes and worker's strikes in a bid to give government more pressures (Law, 2016; Lee, 2015). Law quoted Councilor Dr. Denny Mong-hwa Huang's speech at a public forum on $1^{\text {st }}$ September 1970 , '98\% of the Hong Kong people today are dominated by a small number of privileged people who use English as the official language. The dominant is a manifestation of inequality. Therefore, the promotion of Chinese as the official language is a human rights movement.' At last, in 1971, the Hong Kong colonial government established the "Committee on the Use of Chinese in Public Affairs" and published four reports, which ultimately gave Chinese and English equal statutory status. In 1974, the colonial government officially revised the Official Languages Ordinance, and Chinese became the official language.

\section{Second 'Chinese' Movement in Hong Kong British-Colonial Governance}

The Second 'Chinese' movement, different from the First 'Chinese' movement's anti-colonial sentiment atmosphere, was the continuation of enthusiastic nationalist leftard Baodiao movement in the late 1960s to early 1970 s, and it is influenced by the disappointment atmosphere from the end of 


\section{Cultural Revolution in PRC.}

Lee (2015) has analyzed that the fuse of the second Chinese movement was the public examination requirement announced by the Hong Kong British government in 1978. The Examinations Authority announced that the government would take over the entrance examinations of the University of Hong Kong and the Chinese University of Hong Kong. Officials announced the required qualifications of the University entrance examinations is the pass in English and any other language, that means, Chinese is not the compulsorily required languages to pass. The university student's organizations such as The Chinese University of Hong Kong Student's Union announced statement that 'requiring that both the English and the Chinese language qualifications be qualified at the same time, and the status of Chinese language should not be dwarfed.' In November 1978, The Chinese University of Hong Kong Student's Union organized a "Teaching in Chinese Open Forum" and launched the "Significance of Cantonese Chinese Education" Signature Campaign for teachers and students in the university. Later, they allied with thirty-four cultural, educational, student and workers unions, and formed 'Chinese Campaign Joint Committee' to propose the three primary aims: 1. encourage the authorities to improve further the social status of Chinese, 2. implement mother-tongue Chinese teaching in secondary schools, 3. comprehensively improve the quality of Chinese teaching in secondary schools. Although at last, the British colonial government neglected the above three demands, it only changed back the requirements of the higher-level examinations to the pass in both Chinese and English in the late 1978. Thus, this is the first time Hong Kong people demanded mother tongue Cantonese Chinese, and it should be taught in the official education system in Hong Kong. Mother tongue Cantonese Chinese was officially established in the 1990s by the colonial government.

The official nationalism from the British government of pursuing high status and superior culture of 'English' could be seen as cultural hegemony by keeping the lower status of 'Chinese' in First 'Chinese' Movement. In Second 'Chinese' Movement, the colonial government tried to ensure the elites graduate from the universities allies with the ruling power by their local-elites cooperation and absorption governing strategies. From Gramsci's words, those cultural hegemony strategies are 'as a non-coercive means of maintaining bourgeois dominance in capitalist societies, made and remade the alliances and coalitions in the aggregation of interest's process.'

Furthermore, the undemocratic restriction of Hong Kong locals in participating in parliament and executive government created the political closure of colonial government. It made 'the end of the administrative route' of the local ethnicity in Anderson's words. That means the ethnicity of Hong Kong can only be imagined that Hong Kong is the destination of their places in life since the locals had no chance to elect any seats in mother 'colonial executive or legislative government.' They only could imagine Hong Kong as their final places of administration. In these circumstances, the territory of Hong Kong locals' imagination was created; also, the Hong Kong locals will 
further see themselves as an ethnicity imagined community.

The dominant colonial language policy in English will also create the chance of counter-back from the Hong Kong local's elite. The bilingual talents such as university students and local elites like teachers will be trained, and they can spread the British colonial's oppression in bilingual. These could explain why the First and Second 'Chinese' movements are led by the bilingual youths, which are mostly university students in Hong Kong. In Anderson's explanation, these bilingual youths under colonial governance are majorly part of the imagined community as they will break down the government critiques of pursuing 'fascist racism.' Through learning bilingual, the youths can use mother-colonial government's languages to transform the media's readers, which can be colonizers, to gain support and be part of ethnicity members. Just like Gramsci stated, the youths through the use of bilingual would break the cultural hegemony of the languages, including the languages of schools, newspapers, popular and artist-writers, cinema, radio and religious group by influencing the administrative elites or locals elites within the British-local alliances.

Although the Great Chinese nationalist will argue that the sentiment from 'First Chinese Movement' is risen from the Chinese Patriotism after the 1967 riots, Law (2015), in fact, stated that the pro-CCP's Leftists attitude at that time towards the 'First Chinese movement' is extremely cynical. Thus, he quoted in an article 'About Chinese Status' in Wen Wei Po on 22-08-1970, 'In the "Official Languages", they scored "First Class" and "Second Class". At last, the Chinese were only "Secondary Languages," it became the foil of "First Languages" in English. Is this respect for Chinese? Do not see it. The social movement is just a tattered display of colonialist "democratic" windows.' The rise of 'Second Chinese Movement' also was a great counterargument to the Great Chinese nationalist since enthusiastic nationalist leftard Baodiao movement in the late 1960s to early 1970s is also being influenced and is going downwards by the disappointment atmosphere from the failure of Cultural Revolution in PRC. Enthusiastic Great Chinese nationalist only played catalyst's role, but the central role is still the disappointment experienced due to Cultural Revolution.

The success of these two Chinese Movements has been the evidence to prove the setting up of Cantonese 'Chinese' to become one of the official languages in 1974 and that 'mother-tongue' Cantonese Chinese education in the basic education system in the 1990s is the victory of Hong Kong's locals. The success is a significant leap improvement in the ethnicity-building of Hong Kong as the linguistic nationalism of Hong Kong people is already being accepted by the colonial government.

Anti-Putonghua and Pro-Cantonese Movements in HKSAR governance are the continuations of First and Second 'Chinese' Movement. Once the Hong Kong ethnicity have built up their linguistic nationalism successfully and are accepted by the colonial government, another 'New' 
official nationalism from HKSAR local government from China is likely to prevent the populist linguistic nationalism from the Hong Kong ethnicity through government's necessary educational policies again.

In political structure, HKSAR local government respected andobeyed PRC central government. Putonghua as Medium Instruction (PMI) in Chinese can be seen as the spread of official nationalism and culture hegemony from PRC, the new governor of Hong Kong. Since Putonghua is the official communication medium of PRC government, PMI should be encouraged in Chinese by the name of 'close economic relationship between the Mainland and Hong Kong.' Moreover, the close ties between cultures' and 'Cantonese is a dialect of Chinese language that is not an official legal language' by the HKSAR government aims to lower the status of Cantonese and create a superior culture of Putonghua. In Gramsci's explanation, HKSAR government want to build alliances with PRC government's officials among the 'close economic relationship and culture' interactions. Therefore, changing basic education policies into Pro-PRC policies, PMI in Chinese, have been the tool for the government's alliance made and remade process.

Official nationalism is another similar perspective, although scholars from EdUHK already stated that there is no clear evidence of a positive or negative impact on the effectiveness of Teaching Chinese Languages in Putonghua. Consequently, the official nationalism through languages policy changing is continuing. In Anderson's explanation, official nationalism through HKSAR government languages policy changing is the reaction to and the counter-back to the Hong Kong linguistic nationalism, the official languages of Cantonese 'Chinese' and setting up of 'mother tongue education,' which already developed in previous 'Chinese Movement.' If it is successful, official nationalism can assimilate the ethnicity to become part of their mother-colonial countries nationality members. However, the administrative route of Hong Kong locals is still restricted in HKSAR government. It is so difficult for Hong Kong people to become government officials in China PRC government. The PRC government still neglected the problems of Hong Kong locals in 2018's National People's Congress and the National Committee of the Chinese People's Political Consultative Conference. Same as the 1970s youths in Hong Kong, Scholars Liu (2018) stated that Hong Kong people are 'sub-national' of China. The counter back of the Hong Kong youth movements have proved the developed ethnicity imagined community bonding of the linguistics. Pro-Cantonese, therefore, became one of the symbols of defending own cultures, myth and history of the Hong Kong ethnicity, and the symbol of linguistic nationalism. Unfortunately, the bilingual youth's impacts from Anderson's perspectives is yet still not happening in Hong Kong. Even the Pro-Chinese Movement had characteristics of 'Putonghua Hatred.' As the languages movement is ongoing, researchers should still pay more attention to it. 


\section{Conclusion}

In conclusion, this paper tries to quote Benedict Anderson's works, Linguistic Nationalism, and Gramsci's cultural hegemony as an explanation of Hong Kong's Linguistics nationalist movements. In the Hong Kong context, the nationalism shared similar but stronger localism forms. It is not only focused on local ownership of supplies but also responded to the demands of ethnicity nation ownership. Although the Hong Kong scholars still debate on the rise of the Hong Kong nationalism, this paper insisted that the Benedict Anderson's linguistic nationalism and Gramsci's culture hegemony explain how and why Hong Kong's nationalist movements happen in HKSAR governance such as Anti-Putonghua and Pro-Cantonese Movements. The reason is that Hong Kong locals is defending mother-tongue linguistics, the linguistic autonomy of ethnicity, and the counter-back to cultural hegemony in government's official nationalism since the First and Second 'Chinese 'Movement in Hong Kong British Colonial governance. The effects of the linguistics movements, for example, Chinese as one of the official languages and Cantonese as official teaching languages, has reinforced the linguistic nationalism in Hong Kong to counter-back the official nationalism of culturallinguistic hegemony. This study shows that nationalism and localist movements are not always xenophobic, but it serves as a way to strengthen their imagined community of the ethnicity and defend their ethnicity. Since it shows the importance of Cantonese as a culture combination of Hong Kong ethnicity's ancient history and myth, the nationalism may be raised from the linguistic usage of the territory and the cultural hegemony in official nationalism's impacts. 


\section{References}

1.Anderson, B. (1991). Imagined communities: reflections on the origin andspread of nationalism, Verso, London

2.Anderson, B.(2016). A life beyond boundaries, Verso, London

3.Calzada, I. (2017). "Metropolitan and city-regional politics in the urban age: why does "(smart) devolution" matter?", Palgrave Communications, 3 : 17094.

4.Cheung H Samuel (2002). "21 Shìjì de xiānggăng yuèyǔ yīgè xīn yǔyīn xìtǒng de xíngchéng (Hong Kong in the 21st century Cantonese: The formation of anew voice system) " 《Jinan Journal》。24.2: 25-40。

5.Cheung, T. (2015). "Father" of Hong Kong nationalism? A critical review of Wan Chin's city-state theory. Asian Education and Development Studies. Vol. 4 Issue: 4, pp.460-470, https://doi.org/10.1108/AEDS-07-2015-0032 Curriculum Development Council (2015). "hok6haau6 fo3cing4 ci4zuk6 gang1san1 : zeoi6ziu1 、sam1faa3 、 ci4zuk6 gang1san1 zung1gwok3 jyu5man4 gaau3juk6hok6 zaap6 ling5wik6 fo3cing4 ( siu2 - jat1 zi3 zung1 luk6 ) zi1seon1 gaan2 gaai3(The school curriculum is continuously updated. Focusing, deepening and continually updating the curriculum of Chinese language education and learning (Primary1 to Secondary6). Hong Kong 5.Education Bureau.Available

at:http://www.edb.gov.hk/attachment/tc/curriculumdevelopment/renewal/CLE/brief_CLE\%20KLA.pdf

Curriculum Development Council (1999). "A Holistic Review of the Hong Kong School Curriculum Proposed Reforms." HKSAR Education Bureau. Available at: http://www.edb.gov.hk/tc/curriculum-development/cscurriculum-doc-report/holistic-review/index.html

6.Education Bureau (2008). "SCOLAR intensifies support for schools to teachChinese in Putonghua." Standing Committee on Language Education andResearch. Available at: http://www.info.gov.hk/gia/general/200801/03/P200801030085.htm 7.Francese, J. (2013). Perspectives on Gramsci politics, culture and socialtheory, Routledge, London.

8.Hong Kong Education Bureau (2016). "Fán jiăn zì wèn tí zhèng miàn dì zhèngcè zhèng miàn dì(The problem of traditional or simplified Chinese charactersis positive Policy is positive). Press Release 。Available at::http://www.edb.gov.hk/tc/about-edb/press/cleartheair/20160213.ht 9.Keating, M. (2016). "Contesting European regions," Regional Studies, 51(1), pp. $9-18$

10.Leung-Leung \& Li Li Lily (1997). "Xiānggăng yuèyǔ yǔ xiānggăng wénhuà de guānxì (The relationship between Hong Kong Cantonese and Hong Kong culture) " 。《Dialect》。 1997 (3), P. 183-186。 11.Lo, KC. (2017). "What's Love Got to Do with Ethnic Tensions in Hong Kong?. In: Erni J. (eds) Visuality, Emotions and Minority Culture". The 
Humanities in Asia, vol 3. Springer, Berlin, Heidelberg 12.Loo, J.H.C. (2018). A localist's critique of Hong Kong's political development. Asian Education and Development Studies.

13.Smith, A. D. (1995). Nations and nationalism in a global era, Polity Press, Mass, Cambridge

14.Smith, A. D.(2010). Nationalism, Polity Press, Mass, Cambridge 15.Sonny Lo (2007). "The Mainlandization and Recolonization of Hong Kong: A Triumph of Convergence over Divergence with Mainland China," in Joseph Cheng (ed.), The Hong Kong Special Administrative Region in its FirstDecade (Hong Kong: City University Press), pp. 179-232.

16.So, A. Y. (2011). "One country, two systems" and Hong Kong-China national integration: A crisis-transformation perspective. Journal of Contemporary Asia, 41(1), 99-116.

17.Tse, YK. (1997). "Xiānggăng de duō wénhuà xiànxiàng yǔ găng shì zhōngwén(Hong Kong's multicultural phenomenon and Hong Kong-style Chinese) "。《Dialect 》。 1997.(3)

18.Veg, S. (2017). "The Rise of 'Localism' and Civic Identity in Post-handover Hong Kong: Questioning the Chinese Nation-state," The China Quarterly. Cambridge University Press, 230, pp. 323-347. doi: 10.1017/S0305741017000571. 